\title{
sciendo LEGAL ASPECTS AND STATISTICS OF WORK INJURIES IN THE CZECH REPUBLIC
}

doi:10.2478/mape-2018-0075

Date of submission of the article to the Editor: 03/2018

Date of acceptance of the article by the Editor: 07/2018
MAPE 2018, volume 1, issue 1, pp. 595-601

\author{
Ing. Martina Krügerová, PhD. \\ Dr Mgr. Michal Kozieł, PhD. \\ JUDr. Jana Martiníková, PhD. \\ VŠB - Technical University of Ostrava, Czech Republic
}

\begin{abstract}
By work injury, a health damage or employee's decease are meant if those were caused independently on employee's will by short-period, accidental and violent effect of external impacts while fulfilling working tasks or directly related to it. Also such injury is considered a work injury, which happened when the employee fulfilled his/her working tasks. Legal regulation of the rights and obligations of employers as well as employees as it comes to occupational injuries is being often ignored by both parties of labour-law relationship. In fact, insufficient knowledge of this topic can bring many complications to both parties. It is necessary to keep in mind that not each injury can be considered work injury. The aim of this article is to analyze legal aspects of work injury supported by judicature and statistical data out of segment of work injuries in the Czech Republic. The law is not always clear and allows different explanation, as it also does not consider all situations and questions. Answers to problematic points are more and more often being found in judicature - deciding practice of courts, its conclusions, explanations and statements are evaluated. There is an example of injury happened during a business trip used in this article, by which it will be explained what activities can be thought such relating to working tasks fulfilment. When work injury occurs, the employer is obligated to clarify the reasons and circumstances of it. A monitoring of statistical data of work injuries and their causes seems to be a significant basis when elaborating company risk analyzes, prevention and risk management, occupational health and safety, working conditions and environment.
\end{abstract}

Keywords: labor law, work injury, incapacity for work, business trip, occupational health and safety

\section{INTRODUCTION}

The legal regulation of a work injury and questions related to it is a content of the Labour Code in the Czech Republic (Act No. 262/2006 Coll. as amended). The work injury is defined here as a health impairment or employee's death if it was caused by his independent will by shortterm, sudden and violent effect of external impacts when performance of working tasks or in direct connection with performance of working tasks. Injury, which the employee sustains in relation with working tasks fulfillment, are also considered the work injury.

It has to be taken into consideration that no each injury match a definition of the work injury and each injury is to be assessed individually. Injuries occurred outside the workplace can be also considered the work injury. On the other hand, not all injuries happened at workplaces can be defined as the work injury. The aim of the paper is to analyze the legal aspects of the work injury based on judicature and statistical data out of the segment of work injuries in the Czech Republic.

When evaluated the content of definition of the work injury, the employer has to asses fulfillment of two conditions: (1) whether it is impairment of health or employee's death, cause of which the short-term, sudden and violent effect of external impacts independent on employee's will was (injury action), and (2) whether the health impairment happened when working tasks were fulfilling or in direct connection with it. (Mikyska, 2010). By Kocourek and Dobrichovský (2016), this is a priority question of the employer when he considers further 
steps fulfilling his determined duties. In case, the employer does not make decision or the employee does not agree with this decision, than the court takes action.

By $\S 105(1)$ of the Labour Code, the employer is obligated to consider the causes and circumstances of each incurred work injury. Further, his duty is to keep a book of injuries in which all injuries will be entered including those which did not cause any temporary incapacity from work or which caused temporary incapacity from work not exceeding three days. A register of injury, its description and causes investigation are the important priority process. Possible compensations provided by the insurance companies, by which the employer is insured for case of his liability for damage caused by the work injury or occupational deceases, as well as regress claims of health insurance company are based on it. If the employer or impaired employee violated the "Occupational Safety and Health Protection" rules. For example, Ducháčková $(2015,2013)$ or Chlubna (2015) mention insurance system in the Czech Republic in more detail.

"Good sight of any company is not only quality of products or services, profit or ability to fulfill all customer's request but care of employees and injury rate at workplaces and outside them as well." (Turčan, 2016, p 17). Each employer thus try to avoid work injuries mainly by application of occupational safety and health protection system. As it comes to industrial level, conditions and duties are adjusted by generally obligatory regulations. Often, regular control of the system is more important whether it is set properly and followed. Therefore, administration of continual statistics of work injuries by every employer is thus more than demanded. It can contribute to a deficiencies, weaknesses or deaf places of system discovering. Monitoring of work injuries and their causes statistics can become a significant basis when elaborating the risk analysis, prevention and risk management and $\mathrm{OSH}$, working conditions and environment though. This article will focus on statistical data at macro level thus in the frame of the entire Czech Republic. The statistical data of the Czech Statistical Office, State Labour Inspection Office, State Labour Safety Office, Occupational Safety Research Institute for the years 2007-2017 are going to be considered.

Injury rate can be expressed in different ways, e.g. by the rate of health damage or by ration work injuries/total worked hours. Nevertheless, the basis division of work injuries by the State Labour Inspection Office (2016) is as follows: (i) fatal accident - such health damage is meant, in consequence of which injured employee dies up to 1 year after the accident, (ii) injury with hospitalization longer than 5 days - such health damage is meant, in consequence of which injured employee is hospitalized longer than 5 days, (iii) other injuries - such health damage is meant, in consequence of which the employee become injured with temporary incapacity from work leave longer than 3 calendar days.

\section{RESULTS AND DISCUSION}

As the authors have already introduced, a fundamental thing is to evaluate whether in a concrete case the injury is work-related and whether it matches the definition of work injury. The employer has to evaluate whether the injury happened when working tasks were fulfilled or directly connected with performance of it.

Performance of working tasks by $\S 273(1,2)$ of Labour Code are performance of work duties resulting from the employment (employment relationship) and from agreements on work performed outside an employment relationship, other activity provided due to employer's order and activity being the subject of business trip. Performance of working tasks also activity carried out for the employer at the initiative of the trade union organization, employees' council or representative of occupational safety and health protection or other employees. Own initiative of employees can be also engaged to working tasks fulfillment if the employee does not need any special authorization to provide the activity or he does not do it against expressed employer's ban or it is voluntary assistance organized by the employer. 
By the law ( $\$ 274$ par. 1 and 2 of Labour Code), mainly the following activities have direct connection with performance of working tasks: acts needed to performance of work, acts being usual within the work, acts being necessary before the work beginning and after its finish, acts being usual during the break in the employer's building, check-ups at the doctor being ordered by the employer and ways to and back, first aid medical provision and ways to and back, training of employees being organized by the employer or trade union. There results out of the judicature that the acts directly related to working tasks performance of work are also to be considered activity provided without any external impulse of other persons and are done only based on own employee's decision. Then, direct connection of injury with working task fulfilment is decisive as well as assessment whether it was activity objectively related to employer as it comes to local, time and factual aspects. (NS Cdo 21 2507/2000; NS 21 Cdo 1148/2002).

Work injury, which happened because of working tasks fulfilment is such injury, which is not caused by performance of working tasks neither is in direct connection with performance of working tasks. Other conditions of given definition of work injury are met, i.e. health is damaged or employee died if injury happened independently on his will by short-term, sudden and violent effect of external impacts. Such injuries usually happen outside working hours or at different place than usual working one is. The employer's injury - clerk's one can be used as the example. Injury happened in connection with certain case deciding. The employer was physically attacked by a citizen being not satisfied with the decision of his case; this happened outside the employer's working place and working hours.

In case the work injury would happen, the employer is obligated to compensate the employee's damage or non-proprietary loss resulted from such injury in accordance with $\S 269$ of Labour Code. The liability of the employer to compensate the loss resulting from the work injury is in this case objective, thus there is no need to prove a fault. Such options exist though, which can release the employer from this liability, so called liberation. Liberation comes under the following conditions: (1) by his behavior, impaired employer violated the legal or other regulations or the instructions to follow safety and health protection rules, although he has been properly acquainted with them and knowledge and following of which has been continuously demanded and controlled, (2) the work injury was caused by employee's drunkenness or his use of other addictive materials and the employer could not avoid the damage or non-proprietary loss. If those facts are the only reason for damage or nonproprietary loss, then the employer would be liberated fully. In case the said facts are one of reasons, then the employer would be liberated partially according to the rate of employee's fault. The employer can be also liberated partially if he proves that the employee acted carelessly although being qualified and experienced he knew he can cause the damage to his health. There exists one exception namely when the employee suffers the work injury while avoiding a possible damage of the employer, his properties, life or health if such situation was not caused by the employee himself. In such case, the employer cannot be liberated from his obligation to compensate the damage or non-proprietary loss.

In connection with the determination of the term work injury, there can be mentioned several specific examples, solution of which serves as a guideline when similar case are assessed in practice. The work injury is not only physical injury but any other health damage if it was caused by short-term effect of external impacts. For example, when the employee had to make unusual and sudden effort he is not used to and which is not adequate to his physical abilities. If this fact is one of the important and fundamental causes of health damage, then it is considered the work injury. Myocardial infarction or other vascular accidents can be also considered the work injury if they happen in consequences of extreme stress at the workplace. This named stress can occur either within the working hours or after them. Such injury is thought the work injury which happened because of working tasks fulfilment. Immediate cause of infarction, the mental trauma is as the consequence of one-time overloading when fulfilling especially difficult working tasks. Infarction can be also caused by 
physical trauma as the consequence of one-time non-adequate strain. Sudden vascular accident caused by the fact that superior manager evaluated other employee in unfavorable way and removed him from his position is not considered the work injury. In this case, health impairment was not caused by a work overload but by other reasons. (NS ČR Cpj 37/74)

External cause of injury most often lies in the effect of mechanical impacts such as stumbling, falling, and falling of the weight to the employee. It can be the effect of another impacts such as materials being injurious to health causing acute poisoning, heatstroke when working under direct sun shining or fingers or toes frostbite in winter. It means that concrete harmful conditions can influence the employee's health in unfavorable way and cause health impairment. ((Rc) 5 Co 415/1968)

Recently, there is seen an increasing interests in teambuilding organized by the employers and questions related to work injuries, which happen during those events. It is necessary to point out that such injuries can be considered the work injuries if those happen in the frame of teambuilding activities. On the other hand, if the work injury happens during leisure-time activity, such injury cannot be said the work injury. The teambuilding is the event, purpose of which is to deepen mutual interpersonal relationships of the employees and abilities to cooperate. Formal marking of event is not deciding here but content of activities is. Similarly to this process, customer teambuilding is perceived. Purpose of such event is a taking care of customers by employees, provision with good service and strengthening of mutual relationships. As said above, the content of particular activity has always to be considered when injury happens and it has to be determined whether this activity was doing in the frame of events organized by the employer or was not. Also the Supreme Court of the Czech Republic in its decision No. 21 Cdo 2685/2016 concluded that if in the frame of customer teambuilding the skiing was a part of it and the employer provided his employees with ski passes, it is clear that the employer expected them to ski. Thus if the employee suffered the injury while skiing, it cannot be considered his private "leisure-time activity". This topic is related to injuries happened during the business trip; this theme is mentioned further.

Business trip - Specific process is used when the work injury happened during a business trip is assessed. The law determines that the activity being the subject of the business trip is considered the performance of working duties. The business trip is time-limited employee's sending to perform the work. The employer can send the employee to the business trip only in case the employee agrees to do so. When determining the activity, which is the subject of the business trip, it is necessary to take the content of the term business trip into consideration. Dandová (2004) specifies that the business trip includes employee's transport from his residential address to the place of temporary working place and back; further, it is such activity, which is the subject of the business trip. Such activity being the subject of the business trip is considered working tasks fulfilment. „Transport“ related to the business trip is the act being necessary before the work beginning or after its finish, i.e. activity in direct connection with performance of working tasks. All activities of the employee during his business trip cannot be thought the working tasks fulfillment or acts related to it. Based on particular judicature (NS 21 Cdo 4834/2010) can be stated that the course of the business trip, domestic and foreign ones, has more sections, which cannot be evaluated in the same way as it comes to working tasks fulfilment or direct connection with it. The way from the employee's residential address towards a transport mean is considered the way to working place. It ends by the boarding the transport mean or by entering the station or airport building. The travelling by the transport mean itself to the place, which is the aim of the business trip (and back) is the act directly related to working tasks fulfilment.

The business trip lasting more days is connected with the accommodation in a municipality, in which the employee will fulfill his working tasks. The injury of the employee happened during the way from accommodation place to the working place determined to fulfill the working tasks (or on the way back) is not considered the work injury. This is the part of business trip, the employer is not responsible for injury. This corresponds with the legal regulation involved in 
the Labour Code where it is clearly said that the injury, which the employee suffer during his way to and back from the working place is not considered the work injury. Decision of the Supreme Court No. 21 Cdo 4834/2010 can serve as the example; in this decision the court unequivocally stated that also in case of travelling abroad in the purpose of the business trip lasting more days, the way from accommodation place to the place of working tasks fulfillment and back is perceived as the way to work place (or back); (in this case an employee of university should attend a conference abroad and during his way from the place of conference he was assaulted by unknown attacker and brutally beaten). The injury (as the consequence of attack) is not though considered the work injury by the Supreme Court in sense of relevant regulations of the Labour Code.

\section{STATISTICS}

To prevent the work injuries, general statistics of work injuries in the Czech Republic can be used. Those statistics can become contributive mainly to employers, who, based on them, can adopt suitable measures to decrease the total number of work injuries. Below, the authors present the basic statistical data of work injuries. Statistical data of the Czech Statistical Office, the State Labour Safety Office and the State Labour Inspection Office are elaborated. Absolute number of newly reported cases of temporary incapacity for work due to work injury slightly increased interannually from 47379 cases in 2016 to 47491 cases in 2017 (i.e. by 0,2 \%). Out of this total number, $46870(98,7 \%)$ of the work injuries are those with incapacity for work longer than 3 calendar days. Within the last 10 years, the total number of work injuries with incapacity for work longer than 3 calendar days decreased by $37,5 \%$. (ČSÚ, 2017). In 2017, the lowest number of fatal work injuries was reported. Relative indicator of the number of work injuries with incapacity for work per 100000 sickness insured persons shows similar trend. The table 1 and graph 1 present the entire trend of the number of work injuries in the Czech Republic within 2007-2017.

Table 1

Work injuries in the Czech Republic within 2007-2017

\begin{tabular}{|l|c|c|c|c|}
\hline Year & $\begin{array}{c}\text { Number of } \\
\text { the sickness } \\
\text { insured* }\end{array}$ & $\begin{array}{c}\text { Number of work injuries } \\
\text { with incapacity for work/ } \\
\text { frequency per 100 insured } \\
\text { persons }\end{array}$ & $\begin{array}{c}\text { Work injuries with } \\
\text { incapacity for work longer } \\
\text { than } \mathbf{3} \text { calendar days/ per } \\
\mathbf{1 0 0} \text { insured persons }\end{array}$ & $\begin{array}{c}\text { Number of fatal } \\
\text { work injuries }\end{array}$ \\
\hline $\mathbf{2 0 0 7}$ & 4597021 & $77233 / 1.68$ & $74942 / 1.63$ & 187 \\
\hline $\mathbf{2 0 0 8}$ & 4527443 & $71281 / 1.56$ & $69243 / 1.53$ & 174 \\
\hline $\mathbf{2 0 0 9}$ & 4253139 & $50173 / 1.18$ & $48568 / 1.14$ & 103 \\
\hline $\mathbf{2 0 1 0}$ & 4310960 & $51678 / 1.20$ & $50047 / 1.16$ & 121 \\
\hline $\mathbf{2 0 1 1}$ & 4211549 & $47111 / 1.12$ & $45482 / 1.08$ & 125 \\
\hline $\mathbf{2 0 1 2}$ & 4471889 & $44108 / 0.99$ & $43543 / 0.97$ & 113 \\
\hline $\mathbf{2 0 1 3}$ & 4440326 & $42927 / 0.97$ & $42355 / 0.95$ & 113 \\
\hline $\mathbf{2 0 1 4}$ & 4464057 & $45058 / 0.97$ & $44301 / 0.99$ & 117 \\
\hline $\mathbf{2 0 1 5}$ & 4507012 & $46331 / 1.00$ & $45621 / 10.01$ & 131 \\
\hline $\mathbf{2 0 1 6}$ & 4571305 & $47379 / 1.04$ & $46713 / 1.02$ & 104 \\
\hline $\mathbf{2 0 1 7}$ & 4671825 & $47491 / 1.02$ & $46870 / 1.00$ & 95 \\
\hline
\end{tabular}

* Employees in the Czech Republic are sickness insured obligatory by $\S 5$ of the Act No. 187/2006 Coll. on sickness insurance

Source: (CZSO, 2017; State Labour Inspection Office, 2017; Occupational Safety Research Institute, 2017). 


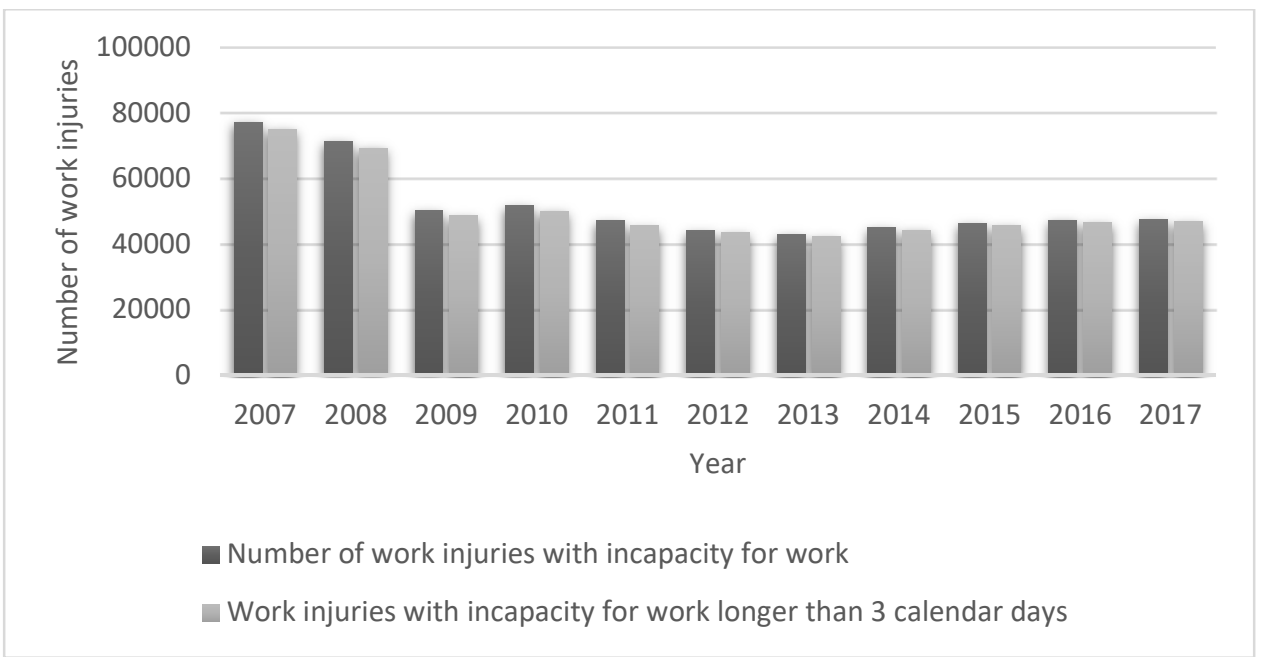

Fig. 1 Trend of work injuries number with incapacity for work in the Czech Republic within 2002-2017

As it comes to connection between work injuries and occupational safety, it is important to monitor the statistics from different points of view. The most often, relation between the work injury and occupation safety is monitored (cause of occurrence, reason) by sections of CZNACE, by company size, by worked hours before injury occurrence. Those statistics serve to e.g. compare the safety level in particular branches. For example Suchomel, Belanova and Vlckova (2013) analyze the development and rate of work accidents in the main activities of agriculture, forestry and fishing.

\section{CONCLUSION}

Once the work injury happens, it is never pleasant issue for both the employer and employee. The work injury can become not only the reason for human suffering, non-fully-fledged life but for premature retirement as well. Work injuries also put the employer in danger as for production or services provision continuity, their quality, they can influence its potential, productivity as well as competitiveness. Costs to compensate the work injury then burden all participants and, in the upshot, entire society pays for it.

By the work injury occurrence, both parties become to follow the rights and obligations. As far as the employer is concern, it is one of the most important questions for him to assess whether the concrete injury is to be considered the work injury and whether it fulfills the definition of it. $\mathrm{He}$ has to evaluate whether the injury happened during the working tasks fulfillment or in direct connection with it or because of working tasks fulfillment. Injuries reporting seems to become fundamental though - keeping the injuries book, detailed description of injury and injury reasons investigation. In case, the employer would argue the employee's claim or the employee would not agree with the employer's decision as it comes to injury, then the court decides. From the point of compensations and possible regresses, there is relation between the work injury and applied occupational safety and health protection system seen at the employer. In case of lawsuits, the employer has to hold the proof burden whether he followed all occupational safety and health protection rules.

The statistics show that the number of work injuries connected with incapacity for work decreases but average period of incapacity for work because of work injury slightly increases. By detailed analysis of statistical data, it can be found, which types of work injuries occur at particular employers or professions the most often. Such findings can be reacted to by implementation of additional preventive measures (trainings, personal protective and safety working aids, implementation of safety elements etc.) aiming at given group of work injuries in order to avoid them. In consequence of it, both employer and employee will be protected 
against negative phenomena connected with the work injury and thus they will prevent later argues and duties resulting from it.

Since 2003, the Czech Republic cooperates in the project "Health and Safety at Work“, the part of which, the statistics of the work injuries ESAW (European Statistics on Accidents at Work) are. The system ESAW monitors the injury rate based on unified methodology (ESAW Summary methodology). A comparison with other countries as it comes to given monitored indicators seems to be a good subject of another paper.

\section{ACKNOWLEDGEMENTS}

This paper was supported under the Operational Programme of Education for Competitiveness - Project no. CZ.1.07/2.3.00/20.0296.

\section{REFERENCES}

CZSO (2017). Incapacity for work for sickness and injury in the Czech Republic in 2017. the Czech Statistical Office.

Dandová, E. (2004). Odškodňování pracovních úrazů a nemocí z povolání. Praha: ASPI Publishing.

Decision of the Regional Court Ústí nad Labem (Rc) 5 Co 415/1968. Law reports and opinions collection 20/1969, ASPI.

Ducháčková, E. (2015). Insurance of Work-related Injuries in the Conditions of the Czech Republic. In 16th Annual Conference on Finance and Accounting, ACFA Prague 2015, Procedia Economics and Finance, Elsevier B.V. pp 200-207.

Ducháčková, E. (2013). Resolving the consequences of work-related injuries in the conditions of the Czech Republic. In 10th International Scientific Conference on European Financial Systems 2013, Masaryk University, pp 79-86.

Chlubna. V. (2015). Effective work injury insurance system and its parametric model. Studies of SocioEconomics \& Humanities, 5(2), pp 6-12.

Judgment of the Supreme Court of the Czech Republic, 5. 1. 2012, sp. zn. 21 Cdo 4834/2010. [online] Available at: www.nsoud.cz. [Accessed 6 June 2018].

Judgment of the Supreme Court of the Czech Republic, 24. 2. 2003, sp. zn. 21 Cdo 1148/2002. [online] Available at: www.nsoud.cz. [Accessed 6 June 2018].

Judgment of the Supreme Court of the Czech Republic, 20.11.2001, sp. zn. 21 Cdo 2507/2000. [online] Available at: www.nsoud.cz. [Accessed 6 June 2018].

Kocourek, J. and Dobřichovský, T. (2016). Pracovní právo pro praxi. Praha: C.H.BECK.

Labour Code, Act No. 262/2006 Coll. as amended.

MIKYSKA, M. (2010). Odškodňování pracovních úrazů a nemocí z povolání. Olomouc: ANAG.

Occupational Safety Research Institute (2017). Analysis of fatal work injuries in the Czech Republic.

Opinion of the Supreme Court of the Czech Republic, Cpj 37/97. Law reports and opinions collection of the Supreme Court - 11/1976, ASPI.

State Labour Inspection Office (2017). Report on work injuries in the Czech Republic.

Suchomel, J., Belanova, K and M. Vlckova (2013). Analysis of Work Accidents in Selected Activities in Slovakia, Czec Republic and Austria. Croatian journal of forest engineering. 34(2), pp 311-320.

Turčan. J. (2016). Snižování úrazovosti a závažnosti v praxi. Praktická personalistika, 2016(11-12), pp. 17-20. 